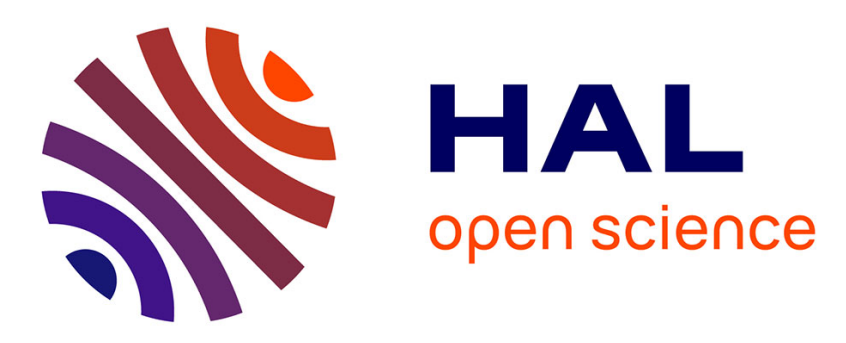

\title{
Grammaticalization in Cushitic, with special reference to Beja
}

Martine Vanhove

\section{To cite this version:}

Martine Vanhove. Grammaticalization in Cushitic, with special reference to Beja. Walter Bisang; Andrej Malchukov. Handbook on Grammaticalization Scenarios: Cross-linguistic variation and universal tendencies, 2, De Gruyter, pp.659-694, 2020, 10.1515/9783110563146-015 . halshs-02447603

\section{HAL Id: halshs-02447603 \\ https://shs.hal.science/halshs-02447603}

Submitted on 21 Jan 2020

HAL is a multi-disciplinary open access archive for the deposit and dissemination of scientific research documents, whether they are published or not. The documents may come from teaching and research institutions in France or abroad, or from public or private research centers.
L'archive ouverte pluridisciplinaire HAL, est destinée au dépôt et à la diffusion de documents scientifiques de niveau recherche, publiés ou non, émanant des établissements d'enseignement et de recherche français ou étrangers, des laboratoires publics ou privés. 
Martine Vanhove

\title{
15. Grammaticalization in Cushitic, with special reference to Beja
}

\begin{abstract}
Reconstructible grammaticalization processes in Cushitic (Afroasiatic) concern mainly the pronominal and verbal domains, markers of subordination, adpositions, question words and discourse particles. Starting with the sole representative of its Northern branch, Beja, this chapter investigates the various sources, targets and paths of 70 grammaticalization processes, seeks for comparable phenomena in three other branches of Cushitic - Central, Highland East and Lowland East - and compares them with the list provided in Heine and Kuteva's (2002) lexicon of the languages of the world, or with other literature about the languages of the Horn of Africa where Cushitic languages are spoken. Four main features of grammaticalization in Cushitic emerge from this investigation: (i) the nominal domain can be a source of grammaticalization, but this not (or hardly) the case for targets; (ii) auxiliaries, in particular the quotative verb which shows a vast array of functions, are often the source of the renewal and enrichment of the verbal system, but this is far less the case for verbless clauses as opposed to other Afroasiatic families, namely Semitic and Egyptian (Cohen 1984); (iii) quotative verbs have a strong tendency to grammaticalize at different levels of the language structure, verbs, complex sentences, discourse, including functions unattested in other genetic stocks; (iv) Cushitic languages show a pervasive semantic link between 'say' and 'purpose' at large.
\end{abstract}

Keywords: Cushitic, Beja, grammaticalization, auxiliary, light verb construction

\section{Introduction}

In this chapter, grammaticalization processes (some of them still on-going) are viewed from a Beja perspective as a starting point (Sections 2-5). They are briefly compared to similar, and sometimes different, processes in a sample of languages from three other branches, Central Cushitic, Lowland-East Cushitic and Highland-East Cushitic (Sections 3-6), which form the closest (or rather less distant) relatives of Beja (the main divisions and geographical localizations of the Cushitic groups are displayed on the map below). A comparative summary of the grammaticalization paths in all four branches and a discussion of their peculiarities is proposed in Section 7. 


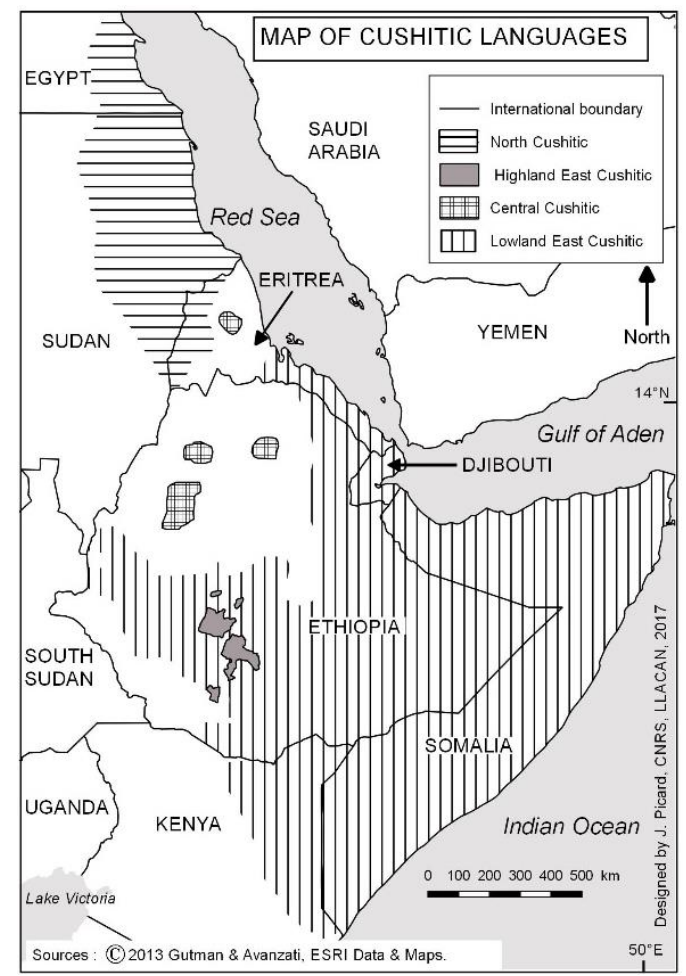

Figure 1: Map of Cushitic Languages.

\subsection{General information about Beja}

The North-Cushitic (NC) branch of the Afroasiatic phylum consists of only one language, Beja, locally named bedawije: $=t$. It is lexically and grammatically quite distant from its closest Lowland East and Central Cushitic relatives, Afar-Saho and Agaw, and is considered as peripheral within the Cushitic family, but the affiliation of Beja to the Cushitic branch is no longer disputed (see Hetzron 1980; Lamberti 1991; Zaborski 1997; Tosco 2000; Appleyard 2004 for a discussion). It is spoken in the northernmost part of the Cushitic-speaking area, mainly in Eastern Sudan between the Red Sea and the river Atbara by approximately 1,100,000 speakers (1993 census, probably even more now), and in Northern Eritrea (approx. 60,000 speakers). It used to be spoken in Southern Egypt, but it seems that (almost?) all speakers have now shifted to Arabic. The first very fragmentary attestations of the language (mainly a few anthroponyms) date back to the 3rd millennium BC until the 7th century AD (see Rilly 2014 for details), but the first comprehensive scientific study and data concerning Beja date back to the second half of the 19th century (Almkvist 1881-1885).

Beja dialectology is ill-known, but dialects do not seem much differentiated. There are three main dialectal zones: North, Centre and South, which have further local and tribal-based subdivisions. These divisions are mainly based on vocalic isoglosses and some lexical peculiarities.

In Sudan, bilingualism with Sudanese Arabic is widespread and expanding, but discredited for women who lead a cloistered life. Beja speakers have a strong awareness of a hierarchy of speech related to rules of honour, politeness, and taboos, correlated to a strong inclination towards allusive speech. Beja is unwritten in Sudan and school education is in Arabic.

\subsection{Typological characteristics}

Within the consonantal phonemes, the alveolar order predominates and is represented by six phonemes while the others have fewer members: 3 bilabials, 3 palatals, 2 retroflex, 2 velars, 2 
labiovelars, 2 laryngeals, and 1 labiodental. The voiceless retroflex consonant $t$ is rare, and there are none of the two pharyngeal fricatives which are reconstructed for proto-Cushitic (Cohen 1988: 251) and still exist in neighboring Cushitic languages. The vowel inventory opposes short and long vowels in an unbalanced way: 4 short vowels vs. 5 long ones. Stress assignment mostly depends on the syllabic structure, and there are no phonological tones.

Beja has a rich and complex morphology, flectional and derivational, both in the nominal and verbal domains. It is partly organized through the interplay of consonantal roots and patterns involving vocalic ablaut in the stem, and also reduplication and affixes in some instances, for verb inflection and derivation, noun formation, verb-noun derivation, adjective and plural formation (this is similar to Arabic, but unlike most Cushitic languages which have at best traces of this system, often limited to noun plural formation). Beja is also partly agglutinative, with suffixes and enclitics (the majority), as well as prefixes and proclitics, which are often portmanteau morphemes.

It is a marked nominative language with three nominal cases for lexical items, two for the verb core arguments, nominative and accusative, and one for noun phrases, genitive. Case of core arguments is marked on determiners by vocalic ablaut (or a consonant in one marginal case), and by vocalic suffixes on nouns for the genitive. Pronouns have in addition dative and ablative sets.

There are two genders, masculine and feminine, and two sets of articles, a proclitic definite one, which partly neutralizes number, gender and case, and an enclitic indefinite one which varies for gender ( $\mathrm{M}$ and $\mathrm{F}$ ) and number (SG and PL), and marginally for case, which surfaces only in some phonological contexts in the masculine.

In the noun phrase, the number and gender of both the possessor and the possessed are indexed on the possessor.

Nouns, pronouns, adjectives, the manner deictics, some interrogative words, and verbs can all be predicates. Verb paradigms have dedicated sets of flectional morphemes, while the other word categories are conjugated with an enclitic copula which varies for number, person, and partially for gender.

Verbs have both finite and non-finite forms. Finite forms are organized along a three-term aspectual system, which distinguishes through flectional morphemes and apophony in the stem a Perfective, an Imperfective and an Aorist which index also the person, number and gender (only in 2 and $3 \mathrm{SG}$ ) of S. There are two morphological verb classes. V1 verbs have prefixed paradigms (except plural indices which are suffixes), or an infix for disyllabic verbs. This is historically the oldest class. V2 verbs have only suffixes, and represent a common Cushitic innovation. Example (1) illustrates V1 verbs for the three paradigms ('kneel', 'have', 'kill'), and V2 for the Aorist ('come').

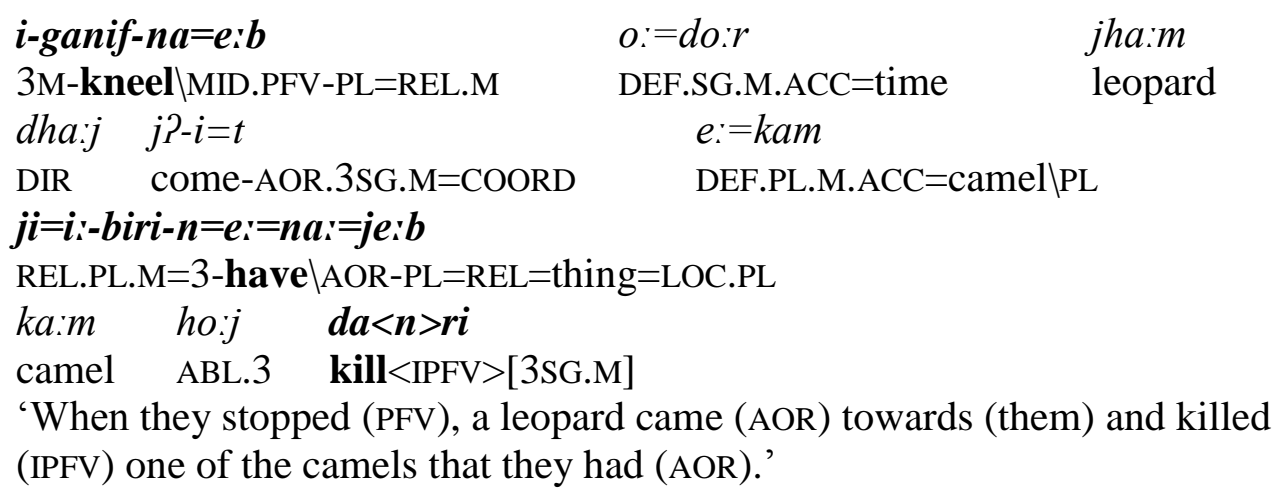

There is, in addition, a rich system of semantic and voice derivation involving ablaut, reduplication and affixal devices (pluractional, intensive, middle, passive, reciprocal, causative, and marginally double causative). The non-finite forms amount to four converbs labelled 
General, Sequential, Simultaneity and Manner converbs. They are invariable, except the Manner converb which may vary for gender in some specific syntactic environments. Only the Simultaneity converb can be negated, with the function of a Privative converb ('without'). This might be because it is the sole converb that can be traced back to a finite form (it has the same morphological pattern as the actual Prohibitive and negative Optative forms). For the other converbs, either coordinate clauses or balanced subordinate clauses are used in negative utterances. The converbs are used in deranked subordinate clauses and as auxiliated forms in complex predicates which will be dealt with in detail in Section 3.

Syntactically, Beja is predominantly head-final, the canonical constituent order is $(\mathrm{X})(\mathrm{S})(\mathrm{O}) \mathrm{V}$, and dependent clause - main clause. Constituent order is not particularly rigid and may vary for pragmatic reasons (for further details, see Vanhove 2017). In the noun phrase, the constituent order is often conditioned by information structure, particularly in relative clauses where the head noun is often topicalized and thus precedes the relative clause.

\section{Grammaticalization of nominal categories}

In most instances, I was not able to trace back the morphology of nominal categories to grammaticalization processes. The clitic feminine morpheme $t$ and the plural devices are panAfroasiatic, the genitive suffix $-i$ goes back to Proto-Cushitic, the indefinite accusative article $=b$ cannot be etymologically related to any free form, nor to another grammatical marker, and the vowels of the nominative and accusative cases are of an unknown origin. We only know that they do not go back to Proto-Cushitic (see Appleyard 2004 for a detailed discussion). The origin of the definite articles is disputed as either a reduction or a reinforcement of former demonstratives (Appleyard 2004: 178-181). Nonetheless, the nominal domain presents three transparent grammaticalization processes that are worth mentioning.

\subsection{The origin of independent personal pronouns}

The second and third person independent personal pronouns (nominative and accusative) are a Beja innovation as compared to other Cushitic languages. They have developed from a verbonominal base, *bar- in the masculine, ${ }^{*} b a(r)=t$ - in the feminine '*possession(s)', which does not survive as such in the language, and to which the possessive enclitic suffixes were added in the appropriate case. This form derives from the verb of possession biri 'have' (Bechhaus-Gerst 1985; Appleyard 2004). A new grammaticalization process is taking place: all six persons, including first persons, can be reinforced with the proximal demonstratives that often procliticize to the pronouns and whose long vowels are often reduced to short ones, as shown in Table 1.

Table 1: Beja independent personal pronouns (Vanhove 2017).

\begin{tabular}{|c|c|c|c|c|}
\hline & \multicolumn{2}{|c|}{ NOM } & \multicolumn{2}{|c|}{$\mathrm{ACC}$} \\
\hline & SG & PL & SG & PL \\
\hline 1 & $(u n=) a n i$ & $($ an $=)$ hinin & $($ on $=) a n e b$ & $($ en=)hinin \\
\hline $2 \mathrm{M}$ & $(u m=) b a r-u:-k$ & $(a m=) b a r-a:-k(n a)$ & $(o m=) b a r-o:-k$ & $(e m=) b a r-e:-k(n a)$ \\
\hline $2 \mathrm{~F}$ & $(u m=) b a t-u:-k$ & $(a m=) b a t-a:-k(n a)$ & $(o m=) b a t-o:-k$ & $(e m=) b a t-e:-k(n a)$ \\
\hline $3 \mathrm{M}$ & $(u m=) b a r-u:$ & $(a m=) b a r-a:$ & $(o m=) b a r-o:$ & $(e m=) b a r-e:$ \\
\hline $3 \mathrm{~F}$ & $(u m=) b a t-u:$ & $(a m=) b a t-a:$ & $(o m=) b a t-o:$ & $(e m=) b a t-e:$ \\
\hline
\end{tabular}


2.2. The origin of the emphatic reflexive pronouns

Among the three devices that form emphatic reflexive pronouns (intensifiers), one is a borrowing from Arabic, but the other two clearly go back to nouns.

The first source is the possessive noun meaning 'owner' kina ( $k n a$ after the definite article), as, e.g., in Manding languages (Creissels this volume), but unlike Manding, it is not limited to the third person and occurs for all three persons in the singular and the plural. It is always used with the definite article and is marked for gender and number. It has three main functions.

Its first use is that of an adnominal intensifier, often for subject and object topicalization. In this case kina has, in addition, an enclitic possessive pronoun referring to the person if the topic is a pronoun (2) but not if the topic is a noun or a demonstrative (3).

(2) ani

$$
i=k n a=j i
$$

bak

1SG.NOM

DEF.M=PRO.REFL=POSS.1SG.NOM

DEICT.MNR

da:-s-e:ti

$a-n d ? i$

be_there-CAUS-CVB.GNRL 1SG-dolIPFV

'As for me, I would let the matter drop.'

(3) to:t

$$
\text { to: }=k n a
$$

PROX.SG.F.ACC

DEF.SG.F.ACC $=$ PRO.REFL

ne:w-e:ti

'As for her, since he insults her...'

insult-CVB.GNRL

The second adnominal function is attributive. It marks possession in one's own right. It occurs after a noun and bears no possessive pronoun.

(4) $i=l i: l i \quad a:=k n a$

DEF.M=eye DEF.PL.M.NOM=PRO.REFL

gwid-a na rh-ja:n=he:b

be_numerous-CVB.MNR thing see-PFV.3PL=OBJ.1SG

'My own eyes (Lit. the eyes themselves) saw many things for me.'

The third function is adverbial, and kina intensifies the meaning of the predicate or the entire clause, and bears no possessive pronoun either.

(5) to: $=k n a$

$a-n a w=h o: b$

DEF.SG.F.ACC $=$ PRO.REFL

1SG-lacklMID.PFV=when

'When I missed her altogether...'

A second set of emphatic reflexive pronouns, less frequent, is built on the same structural principle and goes back to a body part noun biji 'member' still recorded with this meaning in Reinisch (1895: 54), but lost today.

\footnotetext{
${ }^{1}$ All the Beja examples come from data I collected in Sudan between 2000 and 2011 and in Paris in 2014 and 2016. Most of them are available online at http://corporan.huma-num.fr/Archives/corpus.php.
} 


\subsection{The origin of the indefinite pronoun}

As in many languages of the world, the indefinite pronoun 'some, someone, some people' has grammaticalized from the numeral 'one'. In Beja, the plural form may also be used (in addition to the singular).

(6) $\quad 0: n$

$\begin{array}{ll}\text { PROX.SG.M.ACC } & \text { DEF.M=payment } \\ \text { gali }=b & \text { gaw } \\ \text { one } \backslash \text { PL=INDF.M.ACC } & \text { house }\end{array}$

'Having rented a house from someone...' ah-i:t

take-CVB.SEQ

\section{Grammaticalization of verbal categories}

The verbal domain is the most prolific as far as grammaticalization is concerned. The use of periphrastic constructions of various morphological make-ups is well developed for the expression of several TAM, in light verb constructions and in directional constructions. The auxiliary strategy has been the basis of the renewal of verb morphology in the whole Cushitic family. Noteworthy is the fact that in Beja the speech verb meaning 'say' has been recruited to encode a large variety of grammatical and semantic categories, beyond well-known crosslinguistic developments (for Africa, see Güldemann 2008).

\subsection{Renewal of paradigms and light verb constructions}

As mentioned in the introduction, the V2 verb class conjugated with suffixes is a recent innovation in Beja, as in other Cushitic languages. It is usually argued (but see contra Banti 2004, Section 6.2.1 below) that this verb class is the result of the evolution of an auxiliary construction made of a verbo-nominal base and a verb $n / j$ 'say' (or 'be' in other languages) conjugated with prefixes, as Table 2 shows. $^{2}$

This evolution is usually explained by the intermediate stage of a light verb construction as it still exists in Beja and other Cushitic languages, and also as an areal feature in the languages of North-East Africa (see, e.g., Güldemann 2005). In Beja, the verb 'say' can be in the base form (for transitive and intransitive verbs) or in the double-causative and intensive derivation (for transitive verbs only, and onomatopoeias).

Table 2: Comparison of paradigm of $d i$ 'say' and V2 flectional morphemes.

\begin{tabular}{lll}
\hline & 'say' PFV & V2 IPFV \\
\hline 1SG & $a-n i$ & $-a n i$ \\
2SG.M & $t i-n i-j a$ & $-t n i j a$ \\
2SG.F & $t i-n i:$ & $-t i n i:$ \\
3SG.M & $i-n i$ & $-i: n i$ \\
3SG.F & $t i-n i$ & $-t i n i$ \\
1PL & $n i-d i$ & $-n e j /-n a j$ \\
2PL & $t i-d i:-n a$ & $-t e: n(a)$ \\
3PL & $e:-n(a)$ & $-e: n(a)$ \\
\hline
\end{tabular}

(7) faras $=t=i$ :

bak nhal di:-ti:t piercelN.LOC=INDF.F=ABL.SG DEICT.MNR go_up say-CVB.SEQ

\footnotetext{
${ }^{2}$ The original 'say' verb has partially been renewed with another root $d$ in contemporary Beja (present in the Perfective and the Aorist for all persons), hence the non-concordance of forms in 1 and 2 PL.
} 
'After he had gone up quickly through the opening...'

(8) n?a-ti da:-s

be_down-CVB.GNRL be_there-CAUS

$i$-si:s-jo: di-n=ho:b

3SG.M-DBL.CAUS-SaylINT.PFV-PL=when

'When they put it down...'

As can be seen from Table 2, what is still the Perfective paradigm of $d i$ 'say' has become the inflection of the Imperfective of V2 verbs. This is linked to the introduction of a new Imperfective paradigm in Beja, probably prior to the introduction of V2 verb class, which was also partly based on a light verb construction with 'say' (for the singular only) and which resulted in a dramatic change in the aspectual system of Beja via a push-chain: the former Perfective became an Aorist (a form which mainly occurs in dependent clauses and as a past habitual) while the former Imperfective became a Perfective as summed up in Table 3.

Table 3: The evolution of the TAM system in Beja.

\begin{tabular}{ll}
\hline Beja today & Reconstructed forms and values \\
\hline Imperfective & *Verbo-nominal + 'say' (new paradigm) \\
Perfective & *Imperfective ("old present") \\
Aorist & *Perfective ("old past") \\
\hline
\end{tabular}

The arguments in favour of such a change can be summarized as follows: (i) The vowel of the Perfective flectional morphemes is $-a$, while it is that of the Imperfective in most Cushitic languages; (ii) the vowel of the Perfective flectional morphemes is $-i$ in some archaic verbs, as in most Cushitic languages; (iii) some verbs have only two paradigms, the Imperfective and the Aorist (e.g., biri 'have', faj 'be there'); the Present progressive (unknown today) is formed with the Perfective of the core verb and the auxiliaries haj or faj 'be there' in the Imperfective.

As Table 4 below shows, the prefix and infix morphemes of respectively monosyllabic and disyllabic stems of V1 verbs also include * $n$ 'say', with clear traces of pan-Afroasiatic prefixes for the monosyllabic stems: 1SG ?a- (>a- in Beja), 2SG.M, 2SG.F, 3SG.F ti-, 3SG.M ji- (> $i$ - in Beja). A detailed discussion of the evolution is found in Cohen $(1972,1973)$ and Zaborski (1975).

Table 4: Paradigms of the Imperfective of mono- and disyllabic V1 verbs.

\begin{tabular}{lll}
\hline & \multicolumn{2}{c}{ V1 IPFV } \\
\hline & Monosyll. & Disyll. \\
\hline 1SG & an-Ci:C & $a-C a<n>C i: C$ \\
2SG.M & tin- $C i: C-a$ & $C a<n>C i: C-a$ \\
2SG.F & tin- $C i: C-i$ & $C a<n>C i: C-i$ \\
3SG.M & in $-\mathrm{Ci}: C$ & $C a<n>C i: C$ \\
3SG.F & tin- $C i: C$ & $C a<n>C i: C$ \\
\hline
\end{tabular}

\subsection{Valency}

In Beja, voice and valency changing mechanisms are mainly expressed by morphological devices that cannot be reconstructed as the result of grammaticalization. There is only one valency increasing grammaticalized construction which pertains to the domain of applicative, 
namely a construction with a benefactive auxiliary. It is based on the verb $h i$ 'give', as in many languages of the world, but it is a rare device in Afroasiatic. The core verb is either a non-finite form, the General converb, or a finite form, the Perfective (sometimes followed by a linker $-i$ ), or the Imperative if the auxiliary is also in the Imperative.

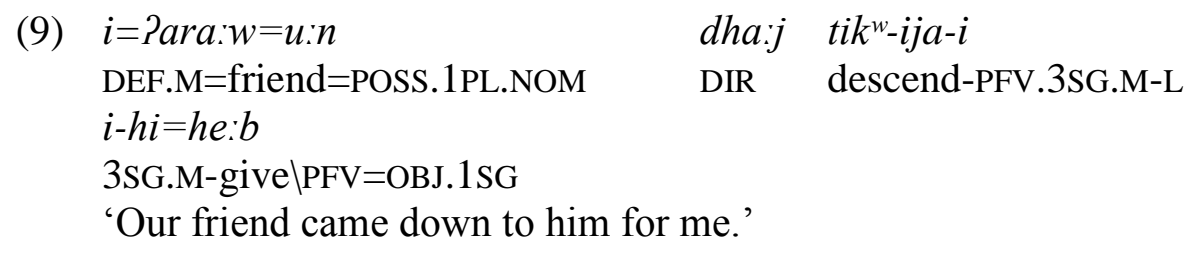

\subsection{Aspect}

\subsubsection{Progressive}

A Progressive aspect marked by a 'be there' auxiliary is reported in Reinisch (1893-1894) for Northern Beja and in Roper (1928) for Central Beja. It is not attested any longer in my Central and Southern data.

\subsubsection{Perfect}

The Perfect aspect developed through the predication of the Manner converb with the copula in main and independent clauses, or the verb $a k$ 'become, be' in negative utterances and dependent clauses.

(10) kak j?-a:=b=wa? how come-CVB.MNR=INDF.M.ACC $=$ COP.2SG.M

'How have you come?'

\subsubsection{Phasal Continuative}

The Phasal Continuative aspect is the result of the grammaticalization of a spatial construction. The verb of centrifugal movement $b a j$ ' $g o$ ' is preceded by the postposition har?a 'after' and by the core verb in the Simultaneity converb form.

$$
\begin{aligned}
& \text { Padaro: }-j a=k a=t \quad \text { aka-je: har?a } \\
& \text { red-PL }=\mathrm{CMPR}=\mathrm{INDF} . \mathrm{F} \quad \text { become-CVB.SMLT after } \\
& i-b e:-n=e: b=k a \\
& \text { 3-golINT.PFV-PL=REL.M=DISTR } \\
& \text { 'It kept becoming redder and redder all the time.' }
\end{aligned}
$$

\subsubsection{Phasal Terminative}

The Phasal Terminative is encoded with a posture verb, $b$ ? $a$ 'lie down'. The core verb may be in the same TAM as the auxiliary or in the form of the General converb.
dirar-ti
$b ?-e: n=e: b$
$o:=d o: r$
dinelMID-CVB.GNRL
lie_down-IPFV.3PL=REL.M
DEF.SG.M.ACC $=$ time
'When they finish dining...' 


\subsection{Modality}

\subsubsection{Intention and volition}

Intention and Volition are expressed with the Manner converb and the auxiliary verb $d i$ 'say'.
baro:k
tam-a: $=h o: k$
e:-d-na
2SG.M.ACC
eat-CVB.MNR=OBJ.2SG
3-saylIPFV-PL
'They want/intend to eat you.'

\subsubsection{Potential}

The potential construction comes from the grammaticalization of the verb of centripetal movement $j$ ? 'come' and the core verb with a multifunctional verbo-nominal suffix -at/-it (only used in complex predicates). It often expresses epistemic modalities of possibility, inference or almost certainty. The core verb is followed by the auxiliary, more or less phonologically reduced depending on the person. The full form of $j$ ? (a highly irregular verb) is used in the $3 \mathrm{SG}, 1 \mathrm{PL}$ and $3 \mathrm{PL}$, it is reduced to flectional morphemes in the $2 \mathrm{SG}$ and $2 \mathrm{PL}$, and omitted in the $1 \mathrm{SG}$.

(14)

$$
\begin{aligned}
& \text { dijar-an=e:k} \quad k a=a-k a n \\
& \text { be_tired-PFV.1SG=if } \quad \text { NEG.IPFV=1SG-knowlMID.PFV } \\
& \text { dabal=had } \quad \text { fi:n-at=aj } \\
& \text { small=until } \quad \text { rest-POT.[1SG]=CSL }
\end{aligned}
$$

'I am really exhausted (Lit. I don't know if I am tired), so I might rest for a while.'

It can also sometimes be interpreted as a future, with a pragmatic connotation of threat.
hinin
rhi-is-at $=0: k$
e:nej
1PL.NOM
see-CAUS-POT=POSS.2SG.ACC
comelIPFV.1PL
'We'll show you!'

\subsubsection{Obligation}

The deontic modality of obligation goes back to a bi-clausal construction that brings into play the expression of identity via the copula or the verb ak 'become, be', and a marker of complement clauses, which itself goes back to a relative clause with a dummy head noun $n a$ 'thing': =e:t to:=na (Lit. REL.F + the thing). It is reminiscent of cleft or pseudo-cleft constructions which are quite frequent in Cushitic languages, but absent in Beja except in an explicative function.

$$
\begin{aligned}
& \text { hanka:j } \quad \text { ho:j } \quad \text { sajjas-i:n=e:t } \\
& \text { before } \quad \text { ABL.3 } \quad \text { think-AOR.3PL=REL.F } \\
& \text { to: }=n a:=t=i \\
& \text { DEF.SG.F.ACC=thing=INDF.F=COP.3SG }
\end{aligned}
$$

'They should have thought about it before.' (Lit. It is the thing that they had thought about before)

\subsection{Tense}




\subsubsection{Future}

Once again, the verb meaning 'say' is used as an auxiliary. In order to express the Future tense, $d i$ 'say', in the Imperfective as in (17) or in the appropriate paradigm requested by the syntax, is associated to frozen forms of the 1st persons SG and PL of the Aorist of the core verb (glossed as FUT and not AOR in the examples). Number concord is often preserved, but not systematically and the singular form of the core verb is gaining over the domain of the plural, more systematically in the Southern variety of Beja than in the Central one.

$$
\begin{array}{lll}
k a k & i:-w r=h e: b & i \text {-jad-na } \\
\text { how } & \text { FUT.SG-do=OBJ.1SG 3-saylIPFV-PL } \\
\text { 'What are they going to do to me?' }
\end{array}
$$

\subsubsection{Immediate future/Prospective}

Immediate future is made of the posture verb $\mathrm{gad}$ 'stop, stand' in a directional construction with the allative postposition $d h a: j /=d a /=d$ 'towards, to'. The core verb is in the form of the masdar (or action noun) in the genitive case.

$$
\begin{aligned}
& \text { Pabu:k-i dha:j=ka } \quad i \text {-ngadi=ja:t=ka } \\
& \text { catchlN.AC-GEN DIR=DISTR } \quad \text { 3SG.M-stop } \backslash \text { PFV=COORD=DISTR } \\
& \text { 'Each time he was about to catch it...' }
\end{aligned}
$$

\subsection{Emphatic constructions}

Two auxiliary constructions are used to emphasize an event in order to reinforce either its truth value or its property. The auxiliaries are not interchangeable and are associated with semantic classes of verbs. The first auxiliary $d i i$ 'do' and the second (highly irregular) one $a h$ 'take' are used either with a General or a Manner converb or with a finite verb form.

$$
\begin{array}{ll}
\text { fidig- } a & d \text { Pi-ja: }=b=u \\
\text { untie-CVB.MNR } & \text { do-CVB.MNR=INDF.M.ACC=COP.1SG } \\
\text { 'I did let it go.' } &
\end{array}
$$
ha:j $\quad$ gab
gab-e:ti
i-ni:n

'He becomes really rich with that.'

\subsection{Contrastive negation}

Rules of honour and politeness have led to an overuse of negative forms. For sake of clarification and insistence on the negation, Beja makes use of the auxiliary verb rib 'refuse' together with a non-finite core verb with the multifunctional suffix -at/-it (here glossed VN). For details, see Hamid Ahmed and Vanhove (2004).

$$
\begin{aligned}
& t=? a b a=t=i \\
& \text { DEF.F }=\text { valley }=\mathrm{INDF} . \mathrm{F}=\text { POSS.1SG.NOM } \\
& \text { t?i-it ti-rib } \\
& \text { resemble-VN 3SG.F-refuselPFV } \\
& \text { 'To me, my valley did not look like it.' } \\
& d h=e \text { : } \\
& \mathrm{DIR}=\mathrm{POSS} .1 \mathrm{SG} . \mathrm{ACC}
\end{aligned}
$$




\subsection{Directional constructions}

With movement verbs, Beja can (but does not need to) specify the trajectory of the movement on the vertical axes by using two posture verbs ?as 'be up' and $n ? a$ 'be down' as auxiliaries. Contrary to the other complex verb constructions, these verbs precede the core verb, a trace of their bi-clausal origin where converb clauses usually precede the main clause. The posture verbs can be in the General converb form, or conjugated in the same TAM as the core verb or, in the Southern variety, have a special form with an $-i$ suffix which only occurs in this context.

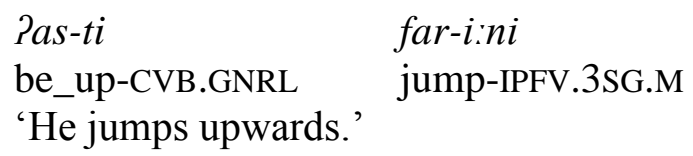

$$
\begin{aligned}
& l u: l \quad n ?-i \quad \text { gid-a } \\
& \text { rope be_down-SUF throw-IMP.SG.M } \\
& \text { 'Throw the rope down!' }
\end{aligned}
$$

On the horizontal axis two different grammaticalized strategies are used.

A centrifugal movement is expressed by similar means as the ones on the vertical axis, namely by the General converb of the verb fidin 'go away', which is followed by the core verb (24). The two elements of the complex predicate may be separated by an ablative pronoun indicating the reference point (25). The bare stem of fidin is used with posture core verbs (26).

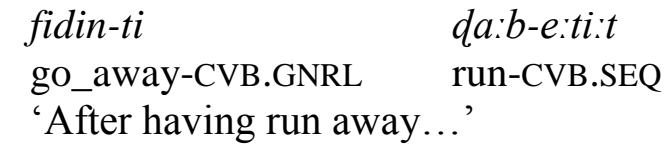
$t=$ ?a:rbi
fidin-ti
ho:so: $\quad$ gid-ti=ho:b
DEF.F $=$ draw $\backslash N$.AGN go_away-CVB.GNRL
ABL.3 throw-AOR.3SG.F=when

'When water collecting people were throwing (stones) (to chase him) away from them...'

$$
\begin{array}{lll}
\text { fidin } & \text { ho:si } & i-s ? a \\
\text { go_away } & \text { ABL.1SG } & \text { 3SG.M-sitlMID.PFV }
\end{array}
$$

'He stayed away from me.'

For a centripetal movement towards a reference point, a nominal construction is involved, rather than a converb. It makes use of a proximal demonstrative and the noun mari 'direction' in the genitive case, without an article, an omission which would be ungrammatical in non-fossilized expressions.

$$
\begin{array}{llll}
w=\text { ?awi } & \text { o:n } & \text { mari-i } & \text { far-ja } \\
\text { DEF.SG.M=stone } & \text { PROX.SG.M.ACC } & \text { direction-GEN } & \text { jump-PFV.3SG.M } \\
\text { 'He jumped over the rock, in our direction.' (Lit. in this direction) }
\end{array}
$$

\section{Grammaticalization of complex constructions}

Leaving aside deranked complement and adverbial clauses with converbs, most complex syntactic constructions of Beja are the result of various nominalization and relativization processes. 


\subsection{Relative clauses}

Apart from a general embedding morpheme $=e$;, the main relative clause markers are clearly cognate with determiners, the definite and indefinite articles, and they agree in gender, number and (usually) definiteness with their head. Indefinite articles ${ }^{3}$ may be followed by the dummy noun $n a$ 'thing' and may combine with the general embedding morpheme. Both types of articles may combine as well, as in (29). Demonstratives are not involved as is commonly the case in African languages (Heine 2011: 706), but it cannot be excluded (although not proven) that the Beja articles ultimately come from former demonstratives.

takat miski: $n=t \quad$ are: $\quad[$ ?arit $\quad$ mhaj=t
woman poor=INDF.F then girllPL three=INDF.F
ti:-biri=t]
$\begin{aligned} & \text { 3SG.F-have } \backslash \text { AOOR=REL.F } f i \\ & \text { 'There was a poor woman then, who had three daughters.' }\end{aligned}$

(29)

$$
\begin{aligned}
& \text { to:t } \quad t i=\text { takat } \\
& \begin{array}{l}
\text { PROX.SG.F.ACC } \quad \text { DEF.F=woman } \\
{[t i=w a w-t i]=t}
\end{array} \\
& \begin{array}{l}
\text { REL.F=weep-AOR.3SG.F=REL.F } \quad r h-i=h o: b \\
\text { 'When he saw this woman who was crying...' }
\end{array}
\end{aligned}
$$

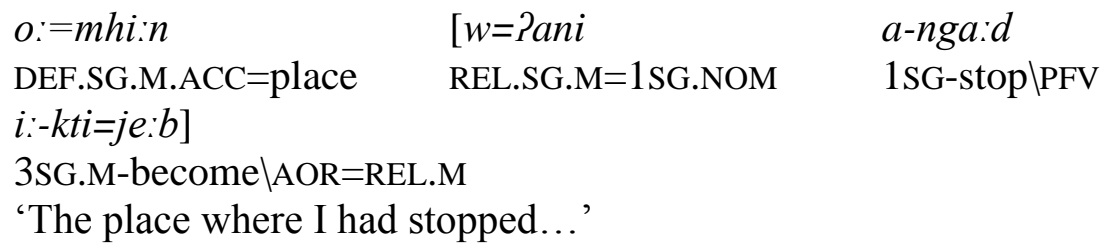

\subsection{Complement clauses}

Complement clauses basically use the same markers as those that form relative clauses, i.e., articles. There are, in addition, dedicated markers for balanced complement clauses: the feminine complex marker $=e: t$, which goes back to $=e:+$ the feminine indefinite article $=t$ (more rarely just the general embedding morpheme $=e$ :) is followed by the dummy noun in its definite accusative form, to: $=n a$ 'the thing'. na may also be used on its own as a complementizer after the simulative verb, but in a deranked construction (ex. 32) with the manner converb in the complement clause.

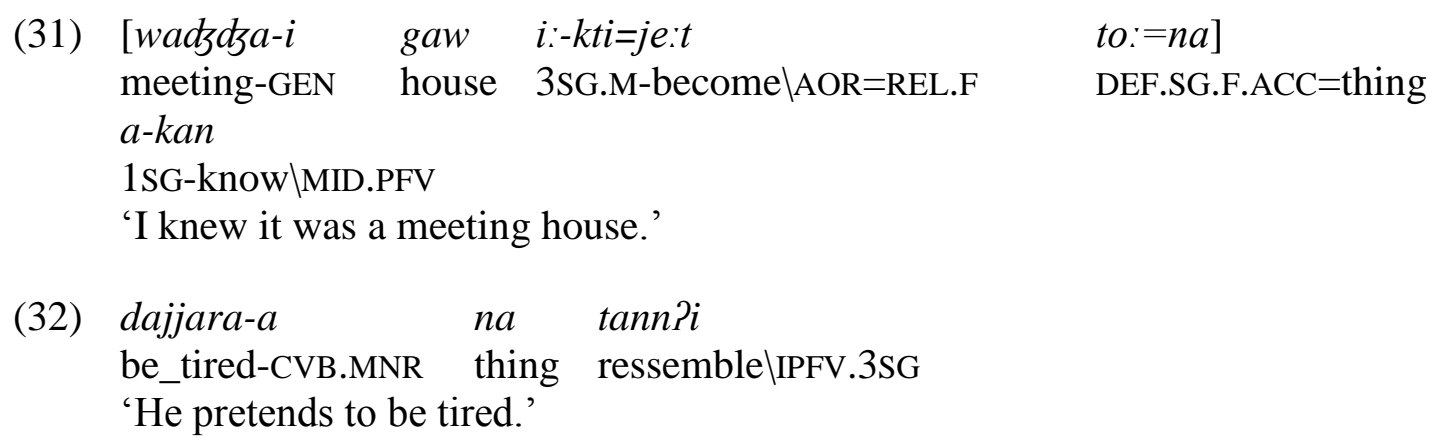

\footnotetext{
${ }^{3}$ For the sake of clarity, the articles functioning as markers of relative and complement clauses are glossed REL and not DEF or INDF in this section.
} 


\subsection{Adverbial clauses}

\subsubsection{Temporal clauses}

The most frequent temporal conjunction comes from a temporal noun ho: $b$ 'time', which survives in the noun phrase $o: n$ ho: $b$ 'at this present time', and has become a temporal marker 'when', which is directly enclitic to finite verb forms.

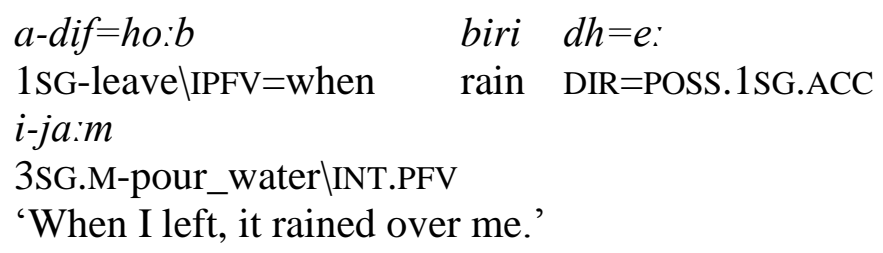

Another marker of temporal adverbial clauses is also based on a temporal masculine noun, do:r 'turn (order of succession), time', a borrowing from Arabic dawr 'period, turn', in its definite form. The construction goes back to a relative clause where do:r behaved as the head. do: $r$ may follow or precede (rarely in my data and always with an additional proximal demonstrative) the relative clause.

$$
\begin{array}{lll}
o:=t a k & \int o: b-a n=e: b & o:=d o: r \\
\text { DEF.SG.M.ACC=man } & \text { greet-PFV.1SG=REL.M } & \text { DEF.SG.M.ACC=time } \\
\text { 'When I greeted the man...' } &
\end{array}
$$

(35) $o: n$

$$
\begin{aligned}
& \text { o:n } \quad \text { o: }=\text { do: } r \\
& \text { PROX.SG.M.ACC DEF.SG.M.ACC }=\text { time } \\
& w i=k^{w i d}-j a: n=e: b \\
& \text { REL.M=disappear-PFV.3PL=REL.M } \\
& \text { 'When they disappeared...' }
\end{aligned}
$$

The following two temporal markers are terminative markers which express the end point of a period of time, 'until'. They also go back to relativized nouns. The first is $=e: b$ hadi:d (Central Beja) where the indefinite masculine noun hadi:d is a borrowing from Arabic meaning 'limit', and the second one is $=e: b o:=k i \cdot k$ (Southern Beja), where the definite masculine noun $o:=k i \cdot k$ means 'the equivalent'. The terminative clause generally follows the main clause.

(36) $\quad 0: n$

$$
i=k a: m=o: k
$$

PROX.SG.M.ACC DEF.M=camel=POSS.2SG.ACC

$h e:=h e: b$

baru:k

givelIMP. [SG.M] $=$ OBJ.1SG

2SG.M.NOM

$o:=b u: n$ $g^{w} ? a-t i=e: b$

hadi:d

DEF.SG.M.ACC $=$ coffee drink-AOR.2SG.M=REL.M

limit

'Give me your camel until you have drunk the coffee.' 
(37)

$\begin{array}{lll}i=j a m-i & d a r & t i-n g a d=e: b \\ \text { DEF.M=waterlPL-GEN } & \text { side } & \text { 2SG.F-Stop } \backslash \text { PFV=REL.M }\end{array}$

$o:=k i \cdot k$

DEF.M.ACC $=$ equivalent

'Until she stopped by the water.'

\subsubsection{Conditional clauses}

Conditional clauses have a dedicated enclitic marker $=e: k$ but when the object of the verb of the protasis is a pronoun, Beja may use the enclitic set of possessive suffixes instead of the object set. This conditional construction is obligatory if the verb is in the Aorist, but optional if it is in the Perfective, for which the possessive set alternates with the $=e: k$ marker and object pronouns. For both verb forms, the use of the possessive set excludes the use of the marker of conditional clauses. Thus, the possessive pronouns in this clause type may be thought of as grammaticalized (portmanteau) markers of conditional clauses.

$\begin{array}{ll}w=h a \text { 'wa:d } \quad j \text { - } i=j u: k & m a j ? a \\ \text { DEF.SG.M=night } \quad \text { come-AOR.3SG.M=POSS.2SG.NOM } & \text { light } \\ \text { rha-tnija } & \\ \text { see-INAC.2SG.M } & \\ \text { 'If night falls upon you, you'll see light' } & \end{array}$

$\begin{array}{ll}a:=j a s & j-P a f i f-n=u: k \\ \text { DEF.PL.M.NOM=dog\PL } & 3 \mathrm{M}-\mathrm{face} \backslash \mathrm{PFV}-\mathrm{PL}=\text { POSS.2SG.NOM } \\ \text { fi:jik fif- } a & h i-j a \\ \text { thorn pour-IMP.SG.M } & \text { give-IMP.SG.M } \\ \text { 'If you meet the dogs (Lit. the dogs faced yours), pour thorns for them!' }\end{array}$

\subsubsection{Concessive clauses}

Concession is expressed with several polyfunctional devices. Most of them are quite frequent crosslinguistically and none of them is fully grammaticalized as a concessive marker in the language. For instance, Beja may use the conditional enclitic morpheme $=e: k$ 'if' or a temporal device, the Simultaneity converb, which may be followed by the additive focus particle han 'also'.
t=ittifa:gija:j
ha:-je:
han Pa:si:-ji:ni
DEF.F=agreement
be_there-CVB.SMLT
also disobey-IPFV.3SG.M
'Even if there was an agreement, he could disobey.'

Another possibility is to use the enclitic morpheme $=k a$, which is a universal quantifier, a distributive marker and a temporal iterative marker when there is no case marker, and a comparative marker when licensing the genitive case. In a concessive sense, in the first construction with $=k a$ the predicate of the adverbial clause is a masdar, while the second construction is inserted in a relative clause. These constructions are not fully grammaticalized and heavily depend on the context for their semantic interpretation.

(41) Ani 1SG.NOM baro:k 2SG.M.ACC ha:jlo: $\quad i-k e:-n$

$$
\text { DM 3-becomelPFV-PL }
$$
$t i-k a t i=h o: b$

2SG.M-becomelIPFV=when sar-o:j=ka

be_awake-N.AC=DISTR

ge: $\quad w=$ ?adil

DM DEF.SG.M=reconciliation 
do:r $h i-i t=o: k=a j$

time give-POT.[1SG]=POSS.2SG.ACC $=$ CSL

'Anyway, in spite of the sleepless nights (Lit. all being awake), since it is you, I grant you the reconciliation.'

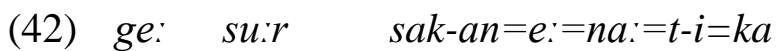

DM before do-PFV.1SG=REL=thing $=$ INDF.F-GEN=CMPR

t?a di:se:t diam ho:j a-mri

so slowly taste ABL.3 1SG-find $\backslash P F V$

'Anyway, in spite of what I did before, I slowly regained confidence.' (Lit. compared to the thing that I had done before I slowly found taste from it)

\subsubsection{Reason clauses}

There is a dedicated enclitic morpheme which marks reason clauses, but oblique relative clauses may also express a causal relation when followed by a locative, directional or ablative postposition. Again, this semantic interpretation heavily depends on the context.

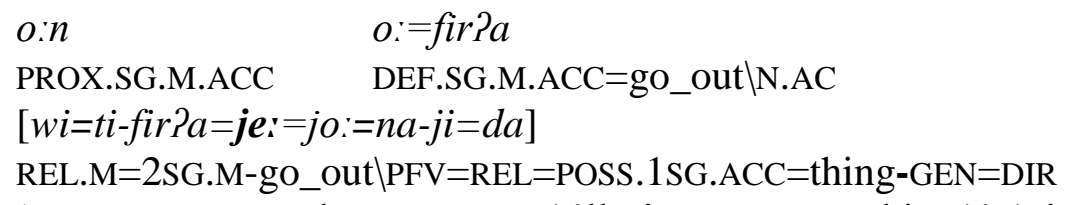

'Because you made me go out (I'll give you something.)' (Lit. this way out towards which you took me out)

\subsubsection{Purpose clauses}

Two different nominalized constructions form purpose clauses. The first one makes use of the directional postposition dha:j 'towards' which licenses the genitive case. The predicate of the purpose clause is a masdar (or action noun).

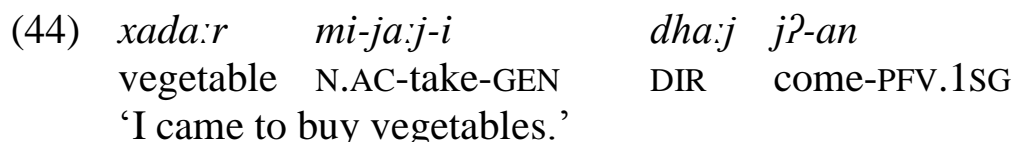

The second nominalized construction has grammaticalized the masdar of the verb 'say', mi$j a: d$, as a purpose clause marker. The verb of the purpose clause is either the Manner converb or the Optative finite paradigm. The clause order is most often the reverse of the canonical one.

$\begin{array}{lcl}n P i & t i-g d h a & t=\text { Po:r } \\ \text { be_down } & \text { 3SG.F-descendIPFV } & \text { DEF.F=child } \\ e:=\text { jam } & \text { baj- } a & \text { mi-ja:d } \\ \text { DEF.PL.M.ACC=water } & \text { golINT-CVB.MNR } & \text { N.AC-say } \\ \text { 'The girl went down in order to go to the water.' } & \end{array}$

\subsection{Insubordination}

Insubordination is part of the origin of most auxiliary constructions where a converb is involved (see Section 3.3).

Insubordination is also attested for the expression of an oath and a wish, in particular in exclamatory contexts. The clause is formally marked as a headless relative clause by a relative 
marker, but the verb of the main clause is omitted in the first case (46), or replaced by a particle in the second one (47).

In the case of an oath, the verbs ba:f or gilad 'swear' are regularly omitted by the speakers.

\section{(46)}

$\begin{array}{llrl}\text { hinin } & \text { to: }=t i j i & t=\text { asarama } & \text { girma-ji } \\ \text { 1PL.NOM } & \text { DEF.SG.F.ACC=snake } & \text { DEF.F=seven } & \text { head-GEN } \\ \text { dir- } a=b & & n i-k a t i=e: b] \\ \text { kill-CVB.MNR=INDF.M.ACC } & \text { 1PL-becomelIPFV=REL.M } \\ \text { '(We swear) that we have killed the seven-headed snake!' }\end{array}$

For the expression of a wish, the non-predicative discourse particle ba:bija, which can roughly be translated as 'if only' and only occurs in clause initial position, is used instead of a desiderative verb, followed by the complement clause.
ba:bija $\quad[$ dibi $-a=b$
PTCL keep-CVB.MNR=INDF.M.ACC
'If only you had kept it!'

\section{Other patterns of grammaticalization and reanalysis}

\subsection{Postpositions}

Like in many languages of the world, most postpositions grammaticalized from body parts and spatial nouns: ge:b 'next to' < 'side', su:r 'before' < 'precedence', daba:j 'forward' < 'face, front' + GEN, whi: 'under' < 'depth', dha:j 'towards' < 'proximity' + GEN, har?i: 'behind' < 'back part', bitka 'between' < 'space, gap', kalawaj 'inside' < 'interior' + GEN. They are all common cross-linguistically.

One postposition with an allative meaning grammaticalized from a General converb, that of the movement verb baj 'go' > be:ti 'towards'.

$$
\begin{aligned}
& o:=r b a \quad \text { be:ti hire:r-e: } \\
& \text { DEF.SG.M.ACC=mountain towards walk-CVB.SMLT } \\
& \text { 'While walking towards the mountain...' }
\end{aligned}
$$

\subsection{Question words}

The polar question marker has been recruited from the scalar additive particle han 'also'.

$$
\begin{array}{ll}
w=\text { hand } i-i=t & n ? a n d a:=t=i: b \\
\text { DEF.SG.M=tree-GEN=INDF.F } & \text { shadow=INDF.F=LOC.SG } \\
t i \text { - } n \text { gad } i \text {-ja } \quad \text { han } & \\
\text { 2-stop\IPFV-SG.M Q.PLR } & \\
\text { 'Do you stay in the shadow of the tree?' }
\end{array}
$$

The selective, non-selective and causal interrogatives come from the feminine dummy noun $n a$ 'thing', a process which is also attested, e.g., in Yucatec Maya (Lehmann this volume) for the non-selective interrogative.

The non-selective interrogative pronoun (also used as a quantitative interrogative adverb 'how much?') is either na:n 'what?' (probably a former reduplicated form of the dummy noun 'thing' as the following form shows), or a reduplicated form with the feminine indefinite article $=t$ and the copula $n a \sim n a:=t=i$. The selective interrogative pronoun is just the dummy noun in 
its bare form for masculine with a lengthening of the vowel, $n a$ : 'which?', and with the indefinite article for feminine, $n a:=t$. In the feminine it is also used as a quantitative ("how much?") or locative ('where?') interrogative adverb.

The causal interrogative adverb is also based on the reduplicated form of the selective interrogative but combined with a spatial postposition, either the ablative one $n a: \sim n a:=t=i$, or the directional one, na: na:t-i=da 'why?'4

\subsection{Discourse particles}

\subsubsection{2nd person dative independent pronoun}

The 2nd person dative independent pronoun ho:k (or $=h o: k$, the enclitic object pronoun, after the similative morpheme) is used at discourse level as an adverbial intensifier.

\begin{tabular}{|c|c|c|c|}
\hline$i=x a r t u: m=w a$ & winne:t & $h o: k$ & madi: $n a=t$ \\
\hline $\begin{array}{l}\text { DEF.M }=\text { Khartoum=COORD } \\
b i=t-k a: j=i\end{array}$ & plenty & $\begin{array}{l}\text { 2SG.DAT } \\
\text { do:r }\end{array}$ & town $=$ INDF.F \\
\hline NEG.OPT=3SG.F-becomeloP & EL & time & \\
\hline
\end{tabular}

(51)

$\begin{array}{lll}o: n & \text { su:r- } n=e: t=h o: k & \text { miski:n } \\ \text { PROX.SG.M.ACC } & \text { before-L=SIMIL.PL=OBJ.2SG } & \text { poor } \\ \begin{array}{ll}\text { ak-e:ti:t } & \\ \text { become-CVB.SEQ } & \end{array} \\ \text { 'After he had become poor as before...' }\end{array}$

\subsubsection{Perfective 3PL of $d i$ 'say'}

The quotative verb $d i$ 'say' in the Perfective 3rd person plural, $e: n$, is frequently used to mark the end of a discursive unit (of whatever length) in narratives and poetry.

\begin{tabular}{|c|c|c|c|}
\hline$u: n$ & $u:=t a k$ & $k^{w} a k^{w} a r=t$ & \\
\hline M.NON & DEF.SG.M.NOM=man & adder=INDF.F & \\
\hline ambal?a:j & $\operatorname{sank}^{w} i=t$ & rhi-i:ni & $e: n$ \\
\hline & $\begin{array}{l}\text { chaselIPFV. [3SG.M] }=\text { INDF.F } \\
\text { s an adder that is chasing al }\end{array}$ & $\begin{array}{l}\text { see-IPFV.3SG.M } \\
\text { (Lit) they said, }\end{array}$ & say\PFV.3PL \\
\hline
\end{tabular}

Japanese also uses a quotative in a comparable way, as a 'sentence-final'/'turn-final' particle (Thompson and Suzuki 2011: 676). The verb 'say' is also integrated in various complex sentence-final particles in Korean (Rhee 2011: 768).

\section{Comparative outlook}

A third of the above-mentioned grammaticalization patterns found in North-Cushitic are at least sporadically attested in other Cushitic languages. On the other hand, Beja lacks other grammaticalizations that occurred in the rest of the family and, beyond that, in the languages of North-East Africa from other families and phyla where several convergence phenomena are attested (for Ethio-Semitic and Highland East Cushitic, see Crass and Meyer [2008]). It is impossible to list them all for lack of space, but in what follows, I will briefly outline the

\footnotetext{
${ }^{4} n a$, in its indefinite form $n a=t$, has also given rise to a negative indefinite pronoun 'nothing'.
} 
commonalities and most salient differences between North-Cushitic and a sample of languages from its closest relatives, Lowland East Cushitic (LEC: Afar, Arbore, Dhaasanac, Konso, Oromo, Saho, Southern Somali [= Tuni]), Highland East Cushitic (HEC: Alaaba, Hadiyya, K'abeena, Kambaata, Sidaama), and Central Cushitic (Agaw) (CC: Awngi, Xamtanga), on the basis of available descriptions and Cushitic comparative studies.

\subsection{Nominal categories}

None of the above three nominal categories in Beja have grammaticalized from the same source in other Cushitic languages.

Cushitic languages have undergone various innovations for personal pronouns, but none of them involves a have-possessive construction. Demonstratives may sometime have played a role in the renewal process of personal pronouns but differently from Beja. This is hypothesized for HEC Alaaba by Schneider-Blum (2007: 169), for which she assumes that the demonstratives were attached to pronouns to become case/gender markers. If this analysis is correct, then it is not restricted to personal pronouns, but it also concerns nouns (Y. Treis, personal communication). Noteworthy from a crosslinguistic perspective are the new plural forms in HEC Kambaata which resulted from the reinforcement of the old plural pronouns by an associative plural morpheme (Treis 2008a: 333). This is also the case in CC Xamtanga (Darmon 2015: 96).

As often in the languages of the world, and notably in African languages (Heine 2011: 700 702; König and Siemund 2013), reflexive emphatic pronouns stem from various body parts such as 'neck' (CC Xamtanga, Darmon 2015: 101), 'hand' or 'head' (LEC Konso, Ongaye 2013: 134), or from 'person' gagá < 'very close person, person of one's kin-group, person who is like oneself' (e.g., HEC Kambaata, Treis 2008a: 217-218, and Alaaba, Schneider-Blum 2007: 188). Treis (p.c.) mentions that gaga also means 'owner' in Kambaata, as in the Beja emphatic pronouns. The source 'member' is not attested elsewhere in Cushitic in the literature I consulted, nor is it attested in Arabic, Tigre and Nubian, the contact languages of Beja.

There is rarely any information about indefinite pronouns in the grammars I consulted. In HEC Kambaata (Treis 2008a: 395) and K'abeena (Crass 2005: 134) they stem from the numeral 'one' as in Beja. K'abeena has in addition 'people', and Kambaata interrogatives. In CC Xamtanga (Darmon 2015: 108), interrogatives (for negation only) are also a source for indefinite pronouns as well as the universal quantifier + a proximal demonstrative.

\subsection{Verbal categories}

\subsubsection{Renewal of paradigms and light verb constructions}

As mentioned in Section 3.1, it is generally considered that the renewal of the finite verb paradigms with flectional suffixes in other Cushitic languages also partly go back to a light verb construction with a verb meaning 'say' conjugated with prefixes (for a different hypothesis based on phonological and analogical processes of inherited cognates of the Afroasiatic stative conjugation, see Banti [2004]). According to Banti (2004: 33-39), in most HEC and CC languages the suffix verb type of Beja, which he supposes was inherited from the Afroasiatic stative, does not occur in independent or main clauses but can be traced back in converb forms.

Cushitic languages also use light verb constructions (LVC) with pragmatic values which vary to some extent from one language to another (for detailed surveys in Cushitic and beyond see Appleyard 2001; Cohen, Simeone-Senelle, and Vanhove 2002; Güldemann 2005; Meyer 2009). 'Say' LVC-s may be used with ideophones (e.g., LEC Konso, Ongaye 2013: 247-253; HEC K' abeena, Crass 2005: 229) and borrowings, or with ideophones and nouns, then extended to intransitive verbs (transitive verbs are often used in LVC-s with a transitive auxiliary such 
as 'do' or 'put' for instance), or may be attested for (almost) all parts of speech, including transitive verbs, sometimes together with derived forms of 'say' (e.g., CC Xamtanga, Darmon [2015: 289]). They can also be more integrated phonologically and morphologically into the verbal complex for certain word classes, as e.g., in LEC Saho with ideophones and nouns (Banti and Vergari 2005: 108). According to Güldemann, what makes the constructions in Cushitic languages, as well as Semitic and Nilo-Saharan languages of North-East Africa, different from similar constructions elsewhere in the world is the co-occurrence of a set of features that are reproduced hereafter:

1) A semantically generic verb serves as the inflectional basis of complex predicates;

2) The respective verb is usually also used in reported discourse;

3) The range of content signs converted into predicates/verbs is fairly wide;

4) The auxiliary occurs after the content sign;

5) The complex predicates tend to merge to a one-word sign. (Güldemann 2005: 141)

\subsubsection{Valency}

'Give' as an applicative auxiliary with a benefactive value is also attested in one CC language, Xamtanga (Darmon 2015: 194-196), but, contrary to Beja, it belongs to a three-term applicative system which has recruited two other auxiliaries meaning 'leave, abandon' (with a malefactive reading) and 'say'. The 'give' strategy, frequent cross-linguistically, is absent in the other Cushitic languages of my sample. Instead, they often have a benefactive verbal derivation or have recourse to a periphrastic construction with a converb of 'say' and a copula, an areal feature in languages of Ethiopia, as for instance in HEC K' abeena and Libido (Crass and Meyer 2008: 243).

\subsection{Aspect}

\subsubsection{Progressive}

Progressive is often grammaticalized in Cushitic languages, stemming from a construction with subordinate core verbs and 'be' verbs (LEC Afar, Bliese 1981: 117; Konso, Ongaye 2013: 161), or copulas (CC Xamtanga - together with a durative morpheme, Darmon 2015: 209; HEC Alaaba, Schneider-Blum 2007: 113, 220).

\subsubsection{Perfect}

In Cushitic languages that have developed a new Perfect aspect (sometimes in addition to an already existing Perfect), constructions with converbs and auxiliaries have been recruited. One of the CC Xamtanga constructions is similar to Beja, namely the 'generic' Perfect formed with a converb and an existential semi-copula (Darmon 2015: 210). The other construction which marks the "experiential Perfect" is based on a converb and the verb 'know' (Darmon 2015: 212), as in HEC K'abeena (Crass 2005: 192) or Alaaba (Schneider-Blum 2007: 253) for instance, an areal feature of the Ethiopian area (Crass and Meyer 2008: 244). In all these languages, the "experiential Perfect" co-exists with a non-periphrastic Perfect (in opposition to Perfective and Imperfective). In LEC Afar, the Perfect is made of an auxiliary meaning 'have' and a converb (Bliese 1981: 119). 


\subsubsection{Phasal Terminative}

Only one grammar mentions a grammaticalized Phasal Terminative construction. In HEC K'abeena (Crass 2005: 190) (and also in HEC Kambaata, Y. Treis p.c.), the auxiliary construction is built from a verb meaning 'stand up, get up', the antonym of Beja 'lie down'.

\subsection{Modality}

\subsubsection{Intention and volition}

CC Xamtanga (Darmon 2015: 283-284) and HEC K'abeena (Crass 2005: 321) are the sole other Cushitic languages where I could find mention of 'say' as a device to express intention and volition. In Xamtanga, the formal means involve a purposive subordinate or a jussive verb form introduced by the converb form of 'say', while in K'abeena these modalities are just contextual and not grammaticalized.

\subsubsection{Obligation}

The expression of deontic obligation by a bi-clausal (pseudo-)cleft construction with an identificational copula or 'be' verb is also attested in two LEC languages, Afar (Bliese 1981: 55) and Somali (Tosco 1997: 136). Some other languages have grammaticalized obligation via 'exist', or verbs with an intermediate stage of possessive 'have' constructions with a verbal noun (but not with a cleft or relative clause), such as HEC K'abeena (Crass and Meyer 2008: 245), or 'be' verbs with a purposive paradigm as in CC Xamtanga (Darmon 2015: 223).

\subsection{Tense}

\subsubsection{Immediate future/Prospective}

None of the other branches of Cushitic has grammaticalized the verb 'say' as a Future auxiliary. HEC Kambaata, Alaaba, K'abeena, and Sidaama (Treis 2012) all have same subject purposecleft constructions that are used to express imminent and/or intended future events. Other future constructions are based on dative-marked verbal nouns which have also given rise to either imminent or intended future, or both. This is the case in one LEC language, Oromo, and one HEC language. It involves a verbo-nominal form with a dative case and a copula (Crass and Meyer 2008: 241-242).

\subsection{Complex constructions}

\subsubsection{Relative clauses and cleft constructions}

Relative clauses or cleft constructions involving nominalizations via the dummy noun 'thing' are also known in LEC Sidaama (Kawachi 2007: 620) and Afar (Simeone-Senelle, Vanhove, and Houmedgaba 2000).

The determiner strategy is attested in LEC Dhaasanac (Tosco 2001: 282) for restrictive relative clauses and CC Awngi (Hetzron 1969: 17) for cleft sentences.

HEC Alaaba (Schneider-Blum 2007: 363), and Kambaata (Treis 2008b: 165-166) have only prosodic cues. In Kambaata, a stress shift to the final position is accompanied by the voicing of the final otherwise devoiced vowel of the verb in main clauses for verb forms ending in a vowel, and for some particular forms by the loss of sub-morphemic glottal appendices. 
In all branches there are often specialized verb forms to mark relative clauses. In CC Agaw for instance these paradigms go back to auxiliary verbs meaning 'be' or 'say' (Appleyard 2002). But in HEC Sidaama, Hadiyya and Kambaata, Hudson (1976: 269) a final vowel is dropped (+ in Hadiyya the 2nd subject agreement marker).

\subsubsection{Complement clauses}

Complement clauses are built upon (headless) relative clauses in LEC Arbore (Hayward 1984: 319-320), Somali (Tosco 1997: 132), Afar (Bliese 1981: 13), and Dhaasanac (Tosco 2001: 286), where the verb of the complement clause is nominalized as a verbal noun, and in CC Xamtanga (Darmon 2015: 239). Similar to Beja, Afar also involves a suffix whose origin is a dummy noun 'thing' (Bliese 1981: 13). In HEC Alaaba, Schneider-Blum's (2007: 391) interpretation of the conjugated converb form of 'say' as a complementizer after verbs of propositional attitude ('think', 'doubt' and 'hope') is debatable. It resembles a pan East-Cushitic use of direct reported speech in this context introduced by the quotative verb at a converb form which is not analyzed as a complementizer for other HEC languages (Y. Treis, p.c.). More frequent in Cushitic is the similative morpheme 'like' as a source of markers of complement clauses (Treis 2017).

\subsubsection{Adverbial clauses}

Usually alongside other devices, adverbial clauses derived from relative clauses or complement clauses are attested in all three Cushitic branches, e.g., in HEC Arbore (Hayward 1984: 319320), and Kambaata (Treis 2012: 189), in LEC Somali (Tosco 1997: 136), Dhaasanac (Tosco 2001: 282-286), and Konso (Ongaye 2013: 231-241), and in CC Xamtanga (Darmon 2015: 237).

\subsubsection{Temporal clauses}

As in Beja, temporal clauses involve a head noun meaning 'time' or 'period' (not cognate with the Beja nouns) in HEC Alaaba (Schneider-Blum 2007: 375), and Kambaata (Treis 2012: 191), in LEC Somali (Tosco 1997: 136), Afar (Bliese 1981: 62), Arbore (Hayward 1984: 569), and Dhaasanac (Tosco 2001: 284), and in CC Xamtanga (Darmon 2015: 248). In e.g., LEC Konso a relative pronoun without a head noun may just also be used (Ongaye 2013: 238).

The marker of Terminative temporal clauses in HEC Alaaba (Schneider-Blum 2007: 376, n. 178) stems from a boundary verb meaning 'reach'.

\subsubsection{Reason clauses}

Reason clauses may involve spatial and/or directional devices and relative clauses in HEC, LEC and CC. This is the case, e.g., in HEC Alaaba (Schneider-Blum 2007: 373) with 'place' and a dative case. HEC Hadiyya, uses a head noun meaning 'side' (Sim 1989: 315), and LEC Dhaasanach (Tosco 2001: 286) also.

HEC Kambaata (alongside with two other constructions) has a relative construction with the dative case of a noun meaning 'size, extent, amount; capability, ability' (cognate with Hadiyya 'side') (Treis 2012: 196).

In CC Awngi (Hetzron 1969: 20-21), there is no head noun but a dative/ instrumental case suffix on the verb of the relative clause.

In LEC Afar, a relative clause and a suffix originating from the dummy noun 'thing' is used, but, unlike Beja, without a directional or spatial device (Bliese 1981: 27). 


\subsubsection{Concessive clauses}

As Beja, Kambaata marks concessive clauses by a (scalar) additive particle (which consists in the lengthening of the final vowel) (Treis 2015). It is also probably the case in HEC Alaaba (Y. Treis p.c.). Schneider-Blum (2007: 372) analyzes this lengthening as an "emphatic suffix". The additive strategy does not occur in the other sources I consulted.

\subsubsection{Purpose clauses}

Cushitic languages frequently use several strategies to encode purpose clauses. As Beja and many languages of the world, most of them use a directional/dative strategy. Treis (2011:4) mentions LEC Sidaama, Oromo, HEC Kambaata, Alaaba, Kabeena, Hadiyya, probably also HEC Gedeo and Burji. This is also the case in LEC Somali (Tosco 1997: 136) with an adposition meaning 'to', and in CC Xamtanga (Darmon 2015: 255) with a dative case.

Most Cushitic languages, especially HEC ones, also have dedicated verb forms for purposive adverbial clauses (see, e.g., Treis 2010 for Kambaata).

Alternatively, as Treis (2017) shows, what is massively recruited for the expression of purpose clauses in Cushitic languages (sometimes limited to negative purpose clauses) is the similative marker (often derived from a manner deictic), e.g., in CC Awngi and Xamtanga, in HEC Alaaba, Hadiyya, K'abeena, Kambaata, and Sidaama, in LEC Oromo, and Somali, and beyond, in Semitic and Omotic languages of the area.

\subsection{Others}

\subsubsection{Adpositions}

All languages have adpositions whose sources are body parts terms, a frequent grammaticalization process cross-linguistically. Depending on the language and the adposition, they may be more or less grammaticalized. 'Back', 'mouth', chest', 'head', 'belly', 'bottom', 'eyes', 'waist', 'body', 'forehead' have often been recruited as relational devices, but also locational nouns such as 'top', 'ground', 'direction', 'inside', 'front', 'side', 'middle', 'proximity', 'distance', as well as, in CC Xamtanga (Darmon 2015: 45), 'sky, up' and 'down'. 'Opening' is found as a grammaticalized locative postposition in LEC Saho (Banti and Vergari 2005: 124) but with a meaning different from Beja 'gap' > 'between', namely 'before'. HEC Kambaata, according to Treis's (2008a: 202) analysis, has no adpositions, but spatial nouns (in addition to cases) are used to express spatial relations between figure and ground, among them a noun meaning 'middle, center, space between' to express 'between, in the middle of' (for a general overview of this path in African languages, see Heine [2011: 698-699]).

A few adpositions come, or may come, from verbs or copulas: in LEC Afar, the comitative postposition comes from the verb 'have' (Bliese 1981: 74), and in CC Xamtanga two locative postpositions meaning 'in, inside', and 'on, in' may come from a copula for the former, and a verb meaning 'draw near' for the latter (Darmon 2015: 45). None of the languages of the sample seem to have grammaticalized the verb 'go' into a postposition.

\subsubsection{Question words}

Most Cushitic languages of the sample have only recourse to intonation to mark polar questions. When a polar question marker exists, it does not seem to be related to an additive particle.

As for content question words, no other Cushitic language seem to have grammaticalized a dummy noun 'thing' in this function. 


\section{Discussion and conclusion}

Table 5 below compares the grammaticalization paths discussed for all four branches of Cushitic studied in this chapter, organized in alphabetical order of sources. + indicates the presence of a particular path in at least one language of the group, - its absence. Empty cells indicate lack of information in the literature I consulted. The right-hand column mentions the presence $(\mathrm{Y})$ or absence $(\mathrm{N})$ in either Heine and Kuteva's (2002) lexicon, ${ }^{5}$ or in other literature about the languages of the Horn of Africa when in between square brackets [N]. An empty cell in this column just means that Heine and Kuteva's lexicon is not concerned by these grammaticalization processes.

Table 5: Comparison of grammaticalization paths in four branches of Cushitic.

\begin{tabular}{|c|c|c|c|c|c|c|}
\hline Source & Target & $N C$ & $C C$ & $L E C$ & $H E C$ & $H \& K$ \\
\hline 2nd person pronoun & Discourse particle & + & & & & \\
\hline \multirow{2}{*}{ Additive particle } & Polar question marker & + & - & - & - & $\mathrm{N}$ \\
\hline & Concessive clause & + & - & - & + & $\mathrm{N}$ \\
\hline Allative adposition & Purpose clause & + & - & + & + & Y \\
\hline Associative & $\begin{array}{l}\text { Plural (in independent personal } \\
\text { pronouns) }\end{array}$ & - & + & & + & Y \\
\hline \multirow{2}{*}{$\mathrm{Be}$} & Progressive & $(+)$ & - & + & - & Y \\
\hline & Relative verbs & - & + & - & + & $\mathrm{N}$ \\
\hline $\mathrm{Be}+$ relative & Deontic obligation & + & - & + & - & $\mathrm{N}$ \\
\hline Be down & Vertical verbal periphrasis & + & - & - & - & $\mathrm{N}$ \\
\hline Be up & Vertical verbal periphrasis & + & - & - & - & $\mathrm{N}$ \\
\hline \multirow[t]{2}{*}{ Body parts } & $\begin{array}{l}\text { Reflexive emphatic } \\
\text { Pronouns/intensifiers }\end{array}$ & + & + & + & + & $\mathrm{Y}$ \\
\hline & Adpositions & + & + & + & + & Y \\
\hline Boundary / reach & Temporal Terminative clause & + & & & + & $\mathrm{Y}$ \\
\hline Come & Potentional, future & + & - & - & - & $\mathrm{Y}$ \\
\hline Complement clauses & Adverbial clauses & + & + & + & + & \\
\hline \multirow{2}{*}{ Copula } & Perfect paradigm & + & + & & & Y \\
\hline & Progressive & - & + & - & + & Y \\
\hline \multirow[t]{2}{*}{ Copula + dative } & Immediate Future/Prospective & - & - & + & + & Y \\
\hline & Immediate Future/Prospective & - & + & & & Y \\
\hline \multirow[t]{2}{*}{ Copula + purposive } & Future & - & + & & & $\mathrm{Y}$ \\
\hline & Deontic obligation & - & + & - & - & Y \\
\hline Dative & Purpose clause & - & + & - & - & $\mathrm{N}$ \\
\hline $\begin{array}{l}\text { Demonstrative }+ \\
\text { direction }\end{array}$ & Centripetal verbal periphrasis & + & & & & $\mathrm{N}$ \\
\hline Demonstratives & Independent personal pronouns & + & & & + & Y \\
\hline Determiners DEF \& & Relative marker & + & + & + & - & $\mathrm{Y}$ \\
\hline INDF & Complementizer & + & - & - & - & $\mathrm{Y}$ \\
\hline Do & Emphatic auxiliary & + & & & & $\mathrm{Y}$ \\
\hline Equivalent & Temporal Terminative clause & + & & & & $\mathrm{N}$ \\
\hline Exist $>$ have & Deontic obligation & - & - & - & + & Y \\
\hline Gap, opening & Adposition 'between' & + & - & - & - & $\mathrm{N}$ \\
\hline
\end{tabular}

${ }^{5}$ Heine and Kuteva, together with their Chinese colleagues, are preparing an augmented version of their dictionary, which was not issued at the time of the writing of this paper, thus some of the $\mathrm{N}$ in the right hand column might have to be changed to $\mathrm{Y}$. 


\begin{tabular}{|c|c|c|c|c|c|c|}
\hline & Adposition 'before' & - & - & + & - & $\mathrm{N}$ \\
\hline Give & Benefactive & + & + & - & - & $\mathrm{Y}$ \\
\hline \multirow{2}{*}{ Go } & Phasal Continuative & + & - & - & - & Y \\
\hline & Allative adposition & + & - & - & - & $\mathrm{Y}$ \\
\hline \multirow[t]{2}{*}{ Go away } & Centrigugal verbal periphrasis & + & & & & $\mathrm{N}$ \\
\hline & Independent personal pronouns & + & - & - & - & $\mathrm{N}$ \\
\hline \multirow{3}{*}{ Have-possession } & Perfect & - & - & + & - & $\mathrm{Y}$ \\
\hline & Comitative & - & - & + & - & $\mathrm{N}$ \\
\hline & Perfect paradigm & - & - & - & + & $\mathrm{Y}$ \\
\hline \multirow{4}{*}{ Insubordination } & $\begin{array}{l}\text { Auxiliary constructions with } \\
\text { converbs }\end{array}$ & + & & & & \\
\hline & Perfect paradigm & + & & & & \\
\hline & Wish & + & & & & \\
\hline & Oath & + & & & & \\
\hline Interrogative & Indefinite pronoun & - & + & & + & $\mathrm{Y}$ \\
\hline Know & Perfect & - & + & - & + & $\mathrm{N}$ \\
\hline Lie & Phasal Terminative & + & - & - & - & $\mathrm{N}$ \\
\hline One & Indefinite pronoun & + & & & + & $\mathrm{Y}$ \\
\hline Owner & $\begin{array}{l}\text { Reflexive emphatic pronouns/ } \\
\text { intensifiers }\end{array}$ & + & - & - & - & $\mathrm{Y}$ \\
\hline Possessive pronouns & Conditional clause & + & - & - & - & $\mathrm{N}$ \\
\hline Refuse & Contrastive negation & + & - & - & - & $\mathrm{N}$ \\
\hline Relative clauses & Adverbial clauses & + & + & + & + & \\
\hline \multirow{10}{*}{ Say } & Quotative & + & + & + & + & $\mathrm{Y}$ \\
\hline & Light verb construction & + & + & + & + & {$[\mathrm{Y}]$} \\
\hline & Verbal flectional morphemes & + & + & + & + & [Y] \\
\hline & Relative verbs & - & + & - & - & $\mathrm{N}$ \\
\hline & Intention & + & + & - & - & $\mathrm{N}$ \\
\hline & Volition & + & + & - & - & $\mathrm{N}$ \\
\hline & Future & + & - & - & - & $\mathrm{N}$ \\
\hline & Purpose clause marker & + & - & - & - & $\mathrm{Y}$ \\
\hline & Discourse marker & + & & & & [Y] \\
\hline & Benefactive & - & + & + & + & $\mathrm{N}$ \\
\hline Similative & Purpose clause & - & + & + & + & $\mathrm{N}$ \\
\hline Stand & Phasal terminative & - & - & - & + & $\mathrm{N}$ \\
\hline \multirow{3}{*}{$\begin{array}{l}\text { Stand + after } \\
\text { Take }\end{array}$} & Immediate Future/Prospective & + & - & - & - & $\mathrm{N}$ \\
\hline & Emphatic auxiliary & + & & & & $\mathrm{N}$ \\
\hline & Complementizer & + & - & - & - & $\mathrm{Y}$ \\
\hline \multirow{3}{*}{ Thing } & Relativizer & + & - & + & - & $\mathrm{N}$ \\
\hline & Question words & + & - & - & - & $\mathrm{Y}$ \\
\hline & Negative indefinite pronoun & + & & & & $\mathrm{Y}$ \\
\hline \multirow{2}{*}{$\begin{array}{l}\text { Time } \\
\text { Time + relative } \\
\text { marker }\end{array}$} & Temporal clause & + & - & + & - & $\mathrm{Y}$ \\
\hline & Temporal clause & + & + & + & + & \\
\hline
\end{tabular}

A striking feature of Cushitic is the vast array of grammaticalizations (10 in the above table) displayed by the 'say' verbs in all four branches. The co-occurrence of cross-linguistically attested ones (quotative index, light verb constructions) has already been noticed in the literature on Cushitic and the Ethiopian area and related to other features (renewal of verb paradigms, position of the light verb, large combinatorial properties, degrees of grammaticalization) as typical of the North-East African area (see Section 6.2.1), including also 
Semitic and Nilo-Saharan languages. In particular, the renewal of verb paradigms with a 'say' verb is also attested in Nubian (Armbruster 1960), a language of Sudan in contact with Beja. Nonetheless these two grammaticalization paths are among the few that are shared by all four Cushitic branches. Moreover, there are additional grammaticalizations that seem particular to this genetic stock and to some extent to Ethio-Semitic (unrecorded in Heine and Kuteva 2002), and they concern different levels of language structure. Three of them occur only in Beja at the verb level (future, unrecorded in other languages as far as I know but clearly linked with the intentional function), at the complex sentence level (marker of purpose clause), and at discourse level (end of discourse unit). Two concerning verbal modality are shared by Beja with CC (volition and intention), one only concerns $\mathrm{CC}$ for verb paradigms and complex sentences (relative verbs), and one (benefactive auxiliary) concerns three branches except NC. Semantically, there is in the Cushitic languages of the sample a pervasive link of 'say' with 'purpose' at large (intention and volition included), particularly developed in Beja and Xamtanga. As Darmon (2015: 221, 290-284) suggests, this development is ultimately linked to the domain of internal awareness which represents the semantic starting point of the grammaticalization path. As far as the benefactive target (not necessarily with a deputative reading) is concerned, one should note that it is not recorded in Heine and Kuteva (2002), making this feature a good candidate for a largely pan-Cushitic innovation. The list provided in Table 5 actually does not cover all the functions of 'say' verbs in Cushitic languages, and for instance CC Xamtanga (Darmon 2015: 280) has, in addition to those of naming, reported evidence, explanation, negative thoughts attribution, formation of manner deictics, formation of manner/circumstantial phrases, and a valency-changing mechanism: imperative causation. Noteworthy is the fact that it seems that no Cushitic language testifies of a complementizer stage. Of course the grammaticalization of 'say' is not the whole story (like any other grammaticalization), and the constructions in which both the speech verb and verbo-nominal forms occur also play a role in their extensions to other functional domains.

In an Afroasiatic perspective, it is important to mention that in Cushitic, auxiliaries have often been recruited as the source of the renewal and enrichment of the verbal system, but this is far less the case for verbless clauses as opposed to some other Afroasiatic families such as Semitic or Egyptian (Cohen 1984).

Fifteen (sometimes only ongoing) grammaticalization paths of Beja are unrecorded in Heine and Kuteva (2002) as well as in other Cushitic languages, relisted below for sake of convenience.

1) Additive particle 'also' > polar question marker

2) 'Be up' (stative) $>$ trajectory on vertical axis

3) 'Be down' (stative) $>$ trajectory on vertical axis

4) Demonstrative + 'direction' $>$ centripetal trajectory on the horizontal axis

5) 'Gap' > adposition 'between'

6) 'Go away' > centrifugal trajectory on the horizontal axis

7) 'Equivalent' $>$ marker of terminative adverbial clause

8) Have-possession $>$ personal pronouns

9) 'Lie down' > phasal terminative auxiliary

10) Possessive pronouns on verbs $>$ conditional

11) 'Refuse' $>$ contrastive negation

12) 'Say' > future tense

13) 'Say' > marker of end of discourse unit

14) 'Stand' '+ after' > Immediate future

15) 'Take' > emphatic auxiliary 
The functional extensions of most of them are quite transparent semantically, sometimes closely related to other grammaticalization paths mentioned in the literature such as genitive-possession $>$ pronouns, or the incorporation of spatial terms in verb paradigms, and deserve no further comment. More unexpected are the (ongoing) grammaticalizations of 'also' as a marker of polar questions, 'take', and possessive pronouns for which I can offer no explanation yet.

Among the 70 grammaticalizations in Cushitic languages studied in this chapter, 18 occur only in NC, and a further 12 cannot be assessed for lack of information on these domains in the grammars consulted. Among the remaining 40, Beja shares 21 of them with at least one language in any of the other three Cushitic branches. Eight concern all four branches. There are more shared features between NC, LEC and CC (11, 5 NC+LEC, 4 NC+CC, 2 NC+CC+LEC) than between NC and HEC (4), which mirrors lexico-statistic studies on the distance between the various subgroups of Cushitic.

'Be, exist' verbs and copulas are often recruited as markers of deontic obligation including in CC and HEC, but it is noteworthy that only NC and LEC have recourse in addition to a relative/cleft construction for this purpose.

It was not possible within the space constraint of this chapter to review all grammaticalization paths attested in the other three branches of Cushitic and those, that do not occur in NC, but some of them seem to be good candidates for shared innovations, either genetically or areally, and to form a bundle of features that, taken together, could be diagnostic for further research on diachronic evolutions and convergence phenomenon in North-East Africa. Particular instances of these, that seem to be (almost?) restricted to these languages and area, are the recruitment of 'be' and 'say' verbs for the creation of relative verb paradigms, 'know' for the perfect aspect, 'say' as a benefactive marker, and similative morphemes as purpose clause markers (without a quotative marker intermediate stage).

\title{
Acknowledgements
}

My thanks are due to the editors of the volume and to my colleague Yvonne Treis for their valuable and constructive comments. I also gratefully acknowledge the financial support of the Llacan (UMR 8135, CNRS - INALCO - Université Sorbonne Paris-Cité), the ANR projects CorpAfroAs and CorTypo (PI Amina Mettouchi), and the Labex EFL Empirical Foundations of Linguistics ANR-10-LABX-0083) for my research on the Beja language.

\begin{abstract}
Abbreviations
$\mathrm{ABL}=$ ablative, $\mathrm{ACC}=$ accusative, $\mathrm{AOR}=$ aorist, $\mathrm{CAUS}=$ causative, $\mathrm{CMPR}=$ comparative, $\mathrm{COORD}$ $=$ coordination, $\mathrm{COP}=$ copula, $\mathrm{CSL}=$ causal, $\mathrm{CVB}=$ converb, DBL.CAUS $=$ double causative, $\mathrm{DEF}$ $=$ definite, DEICT $=$ deictic, DIR $=$ directional, DISTR $=$ distributive, $\mathrm{DM}=$ discourse marker, $\mathrm{F}=$ feminine, FUT $=$ future, GEN $=$ genitive, GNRL $=$ general, IMP $=$ imperative, INDF $=$ indefinite, INT = intensive, $\mathrm{IPFV}=$ imperfective, $\mathrm{L}=$ linker, $\mathrm{LOC}=$ locative, $\mathrm{M}=$ masculine, $\mathrm{MID}=$ middle, MNR $=$ manner, $\mathrm{N} \cdot \mathrm{AC}=$ action noun $($ masdar $), \mathrm{N} \cdot \mathrm{AGN}=$ agent noun, $\mathrm{NOM}=$ nominative, $\mathrm{OBJ}=$ object, $\mathrm{PFV}=$ perfective, $\mathrm{PL}=$ plural, $\mathrm{POSS}=$ possessive, $\mathrm{POT}=$ potential, $\mathrm{PRO} . \mathrm{REFL}=$ emphatic reflexive pronoun, $\mathrm{PROX}=$ proximal, $\mathrm{Q} . \mathrm{PLR}=$ polar question marker, $\mathrm{REL}=$ relator, $\mathrm{SEQ}=$ sequential, $\mathrm{SG}=$ singular, $\mathrm{SMLT}=$ simultaneity, $\mathrm{SUF}=$ suffix, $\mathrm{VN}=$ verbo-nominal.
\end{abstract}

\section{References}

Almkvist, Herman. 1881-1885. Die Bischari-Sprache Tuu-Bedaawie in Nord-ost-Afrika. Uppsala: Kaiserliche Akademie der Wissenschaften. 
Appleyard, David. 2001. The verb "to say" as a verb "recycling device" in Ethiopian languages. In Andrzej Zaborski (ed.), New data and new methods in Afroasiatic Linguistics: Robert Hetzron in memoriam, 1-11. Wiesbaden: Harrassowitz.

Appleyard, David. 2002. The morphology of main and subordinate verb form marking, with special reference to Ethiopian Semitic and Agaw. Afrikanistische Arbeitspapiere 7. 9-31.

Appleyard, David. 2004. Beja as a Cushitic Language. In Gabor Takács (ed.), Egyptian and Semito-Hamitic (Afro-Asiatic) Studies in Memoriam W. Vycichl, 173-194. Leiden: Brill.

Armbruster, Charles H. 1960. Dongolese Nubian, a grammar. Cambridge: Cambridge University Press.

Banti, Giorgio. 2004. New perspectives on the Cushitic verbal system. In Andrew Simpson (ed.), Proceedings of the Twenty-Seventh Annual Meeting of the Berkeley Linguistics Society (March 22-25, 2001) - Special Session on Afroasiatic Languages, 1-48. Berkeley: Berkeley Linguistics Society.

Banti, Giorgio \& Moreno Vergari. 2005. A sketch of Saho grammar. Journal of Eritrean Studies 4. $1-2$.

Bechhaus-Gerst, Marianne. 1985. 'Du bist, was du hast' - Zur Enstehung neuer Personalpronomen im Tu Bedawye (Beja). Afrikanistische Arbeitspapiere 1. 125-129.

Bliese, Loren F. 1981. A generative grammar of Afar. Arlington: The Summer Institute of Linguistics and the University of Texas.

Cohen, David. 1972. La mutation aspectivo-temporelle dans quelques langues couchitiques et le système verbal chamito-sémitique. In Jacqueline Thomas \& Lucien Bernot (eds.), Langues et techniques, nature et société, 57-63. Paris: Klincksieck.

Cohen, David. 1973. Le renouvellement de l'inaccompli en bédawiye. Comptes Rendus du GLECS 14. 69-78.

Cohen, David. 1984. La phrase nominale et l'évolution du système verbal en sémitique. Etude de syntaxe historique. Leuven: Peeters.

Cohen, David. 1988. Couchitique-omotique. In David Cohen (ed.), Les langues dans le monde ancien et moderne. Langues Chamito-Sémitiques, 243-269. Paris: Editions du CNRS.

Cohen, David, Marie-Claude Simeone-Senelle \& Martine Vanhove. 2002. The Grammaticalization of 'say' and 'do': An areal phenomenon in the Horn of Africa. In Tom Güldemann \& Manfred von Roncador (eds.), Reported speech: A meeting ground for different linguistic domains, 227-251. Amsterdam: John Benjamins.

Crass, Joachim. 2005. Das K'abeena. Deskriptive Grammatik einer hochlandost-kuschitischen Sprache. Köln: Köppe.

Crass, Joachim \& Ronny Meyer. 2008. Ethiopia. In Bernd Heine \& Derek Nurse (eds.), A linguistic geography of Africa, 228-250. Cambridge: Cambridge University Press.

Creissels, Denis. forth (2020). Grammaticalization in Manding languages. In Walter Bisang \& Andrej Malchukov (eds.), Grammaticalization Scenarios. Areal Patterns and CrossLinguistic Variation. A Comparative Handbook. Berlin: De Gruyter, Mouton.

Darmon, Chloé. 2015. A morphosyntactic description of Xamtanga: An Agaw (Central Cushitic) language of the northern Ethiopian highlands. Lyon, France: Université Lyon 2 dissertation.

Güldemann, Tom. 2005. Complex predicates based on generic auxiliaries as an areal feature in Northeast Africa. In F. K. Erhard Voeltz (ed.), Studies in African linguistic typology, 131154. Amsterdam: John Benjamins.

Güldemann, Tom. 2008. Quotative indexes in African languages: a synchronic and diachronic survey. Berlin: Mouton de Gruyter.

Hamid Ahmed, Mohamed-Tahir \& Martine Vanhove. 2004. Contrastive negation in Beja: the auxiliary verb rib. Afrika und Übersee 85. 81-98.

Hayward, Dick. 1984. The Arbore language. A first investigation. Including a vocabulary. Hamburg: Buske. 
Heine, Bernd. 2011. Grammaticalization in African languages. In Bernd Heine \& Heiko Narrog (eds.). The Oxford handbook of grammaticalization, 696-707. Oxford: Oxford University Press.

Heine, Bernd \& Tania Kuteva. 2002. World lexicon of grammaticalization. Cambridge: Cambridge University Press.

Hetzron, Robert. 1969. The verbal system of Southern Agaw. Berkeley, Los Angeles: University of California Press.

Hetzron, Robert. 1980. The limits of Cushitic. Sprache und Geschichte in Afrika 2. 7-126.

Hudson, Grover. 1976. Highland East Cushitic. In Lionel M. Bender (ed.), The Non-Semitic languages of Ethiopia, 232-277. East Lansing: African Studies Center, Michigan State University.

Kawachi, Kazuhiro. 2007. A grammar of Sidaama (Sidamo). A Cushitic language of Ethiopia. New York: Department of Linguistics, University of Buffalo, the State University of New York dissertation.

König, Ekkehard \& Peter Siemund (with Stephan Töpper). 2013. Intensifiers and reflexive pronouns. In Matthew S. Dryer \& Martin Haspelmath (eds.), The world atlas of language structures online. Leipzig: Max Planck Institute for Evolutionary Anthropology. http://wals.info/chapter/47 (accessed 16 February 2017).

Lamberti, Marcello. 1991. Cushitic and its classifications. Anthropos 86. 552-561.

Lehman, Christian. forth. (2020). Grammaticalization in Yucatec Maya. In Walter Bisang \& Andrej Malchukov (eds.), Grammaticalization Scenarios. Areal Patterns and CrossLinguistic Variation. A Comparative Handbook. Berlin: De Gruyter, Mouton.

Meyer, Ronny. 2009. The quotative verb in Ethiosemitic languages and in Oromo. In Joachim Crass \& Rony Meyer (eds.), Language contact and language change in Ethiopia, 17-42. Köln: Köppe.

Ongaye, Oda Orkaydo. 2013. A grammar of Konso. Utrecht: LOT Publications.

Reinisch, Leo. 1893-1894. Die Bedauye-Sprache in Nordost-Afrika, 3 vol. Wien: Sitzungs Berichte der Kais. Akademie der Wissenschaften in Wien L, Band CXXVIII.

Reinisch, Leo. 1895. Wörterbuch der Bedawiye-Sprache. Wien: Hölder.

Rhee, Seongha. 2011. Grammaticalization in Korean. In Bernd Heine \& Heiko Narrog (eds.), The Oxford handbook of grammaticalization, 764-774. Oxford: Oxford University Press.

Rilly, Claude. 2014. Language and ethnicity in ancient Sudan. In Julie R. Anderson \& Derek Welsby (eds.), The fourth cataract and beyond. Proceedings of the 12th International Conference for Nubian Studies, 1169-1188. Leuven: Peeters.

Roper, E. M. 1928. Tu Bedawie. An elementary handbook for the use of Sudan Government officials. Hertford: Austin.

Schneider-Blum, Gertrud. 2007. A grammar of Alaaba. Köln: Köppe.

Simeone-Senelle, Marie-Claude, Martine Vanhove \& Makki Houmedgaba. 2000. La focalisation en afar. In Bernard Caron (ed.), Topicalisation et focalisation dans les langues africaines, 289-309. Louvain: Peeters.

Thompson, Sandra A. \& Ryoko Suzuki. 2011. The grammaticalization of final particles. In Bernd Heine \& Heiko Narrog (eds.), The Oxford handbook of grammaticalization, 668-680. Oxford: Oxford University Press.

Tosco, Mauro. 1997. Af Tunni: grammar, texts, and glossary of a southern Somali Dialect. Köln: Köppe.

Tosco, Mauro. 2000. Cushitic overview. Journal of Ethiopian Studies 33(2). 87-121.

Tosco, Mauro. 2001. The Dhaasanac language: Grammar, texts, vocabulary of a Cushitic language of Ethiopia. Köln: Köppe.

Treis, Yvonne. 2008a. A grammar of Kambaata. Part 1: Phonology, nominal morphology, and non-verbal predication. Köln: Köppe. 
Treis, Yvonne. 2008b. Relativization in Kambaata (Cushitic). In Zygmunt Frajzyngier \& Erin Shay (eds.), Interaction of morphology and syntax. Case studies in Afroasiatic, 161-206. Amsterdam: John Benjamins.

Treis, Yvonne. 2010. Purpose-encoding strategies in Kambaata. Afrika und Übersee 91. 1-38.

Treis, Yvonne. 2011. Purpose clauses in Ethiopian Languages. Paper presented at the 14th Italian meeting of Afroasiatic linguistics, Torino, 15-18 June.

Treis, Yvonne. 2012. Expressing future time reference in Kambaata. Nordic journal of African studies 20(2). 132-149.

Treis, Yvonne. 2015. The additive $-V$ in Kambaata. Paper presented at the 48th annual meeting of the SLE, workshop "additives across languages", Leiden, 2-5 September.

Treis, Yvonne. 2017. Similative morphemes as purpose clause marker in Ethiopia and beyond. In Yvonne Treis \& Martine Vanhove (eds.), Similative and equative constructions. A typological perspective, 91-142. Amsterdam: John Benjamins.

Vanhove, Martine (avec la collaboration de Mohamed-Tahir Hamid Ahmed et Ahmed Abdallah Mohamed-Tahir). 2017. Le bedja. Leuven: Peeters.

Zaborski, Andrzej. 1975. The verb in Cushitic. Krakow: Nakladem Uniwersytetu Jagiellonskiego.

Zaborski. Andrzej. 1997. The position of Cushitic and Berber within Hamito-Semitic dialects. In Alessandro Bausi \& Mauro Tosco (eds.), Afroasiatica Neapolitana. Contributi presentati all' $8^{\circ}$ Incontro di Linguistica Afroasiatica (Camito-Semitica). Napoli, 25-26 Gennaio 1996, 49-59. Napoli: Istituto Universitario Orientale. 